\title{
THE CRISIS OF THE MODERN CITY: THE EXAMPLE OF PORTO ALEGRE
}

\author{
A CRISE DA CIDADE MODERNA: 0 \\ EXEMPLO DE PORTO ALEGRE
}

\section{Luiz Antonio Gloger Maroneze luizmaroneze@feevale.br}

Doutor em História pela Pontifícia Universidade Católica do Rio Grande do Sul (Porto Alegre/Brasil).

Professor na Universidade Feevale (Novo Hamburgo/Brasil). 


\section{ABSTRACT}

This article offers an analysis of the effects of the crisis of modernity in the context of the history of Porto Alegre, starting from the understanding that the city has experienced, in a clear way, the modern imagery and, subsequently, the crisis of such ideas. A review of the literature is also presented, looking at important works written by authors who describe this process in Porto Alegre; subsequently, a dialogue with the great minds that address the topic. It is understood that reflecting upon the urban future and urban projects - as well as how these ideas are rearranged - is imperative to contemporary social sciences.

Keyword: City. Crisis. Modernity. Violence.

\section{RESUMO}

O artigo propõe analisar os efeitos da crise da modernidade no âmbito da História de Porto Alegre. Parte do entendimento de que a cidade vivenciou de forma clara os imaginários modernos e, posteriormente, a crise destas ideias. Faz-se, na sequência, uma revisão dos autores que analisam esse processo no âmbito da capital para, logo depois, dialogar com os principais pensadores que transitam pela temática. Entende-se aqui que refletir sobre os destinos e projetos urbanos, sobre a forma como essas ideias estão sendo reorganizadas é fundamental as ciências sociais contemporâneas.

Palavras-chave: Cidade. Crise. Modernidade. Violência 
"Where is the 'city' today in its compact form and complex structure? Nowhere" Walter Prigge.

\section{INTRODUCTION}

This article promotes some reflection upon the effects of the modernity crisis in Porto Alegre; understanding, however, that this is a process affecting the whole of Western culture. Considering that human reality is established by culture and that the culture is ruled by symbolic processes, radical changes in the world of ideas have effects in all areas of living. As the sociologist Maffesoli observes, reality is imagery, and nothing escapes the ambience of an era. Therefore, reflecting about the downfall of this "concept" - modernity - is crucial to all areas of knowledge, and it demands an interdisciplinary effort in order to approach its multiple problematics.

Several Brazilian cities adopted aesthetic standards that came from major European centers in the beginning of the twentieth century, in an effort to translate and adapt those patterns to local realities. At that time, capital cities such as Rio de Janeiro and Porto Alegre, among others, experienced urban reforms in their centers, searching for an "upgrade" to the new standards. The demand for such changes was coming from a population that, while incorporating the imagery of great European centers, claimed urban reforms from local governments. Literature, film and other media were responsible for receiving the metropolitan aesthetic and behavioral patterns in such a way that the modernity design expressed by the large European and American cities was instantly wanted and projected within the different realities of our main cities.

Nevertheless, the transformation that took place at the time - as usually happens - ended up becoming a blend between "global" and local. In Brazil as a unit, and more notably in the cities, modernity represented a translation of what is possible, with singular ramifications in all areas, from economy to social standards.

The same could be said, perhaps, in regards to the modernity crisis. Throughout the twentieth century, the development of large Brazilian cities occurred in a fast pace and, sometimes, without reasonable planning. The metropolises projected in the 20 s and 30 s resulted in environments that greatly differed from the optimistic utopias of modernity. Chaotic traffic, slums, out-of-control violence, among other aspects, was not the expected outcome; we face a perspective crisis, also felt and expressed by the central Western countries.

The present article approaches how the issues above have been perceived, in the specific case of Porto Alegre, presenting - through different sources and perspectives - elements of modernity and its subsequent crisis. 


\section{MODERNITY AND ITS CRISIS IN PORTO ALEGRE}

Modernity in the history of Porto Alegre is a subject that has received considerable attention from historians, as can be seen by the marked increase in the number of masters' and doctoral researches on the topic. During the 90 s, the compilations ${ }^{1}$ or specific papers emerged, aiming to understand the "modern", its ideas and interpretations within the context of the cities: articles, dissertations and theses undertook investigations on the effects of modernity upon the urban life, social values, etc. It is still a recurrent subject matter of relevant academic works, not only in the specific field of historians, but also gaining a great deal of attention from architects, literary critics and memorialists.

This fact that can be explained, on the one hand, by the emergence and the expansion of postgraduation courses during that time, which significantly expanded the academic view about the past of the city; on the other hand, perhaps even due to changes in the historicity regime, which took place between the 1980s and $1990 \mathrm{~s}^{2}$. The modernization of the city and of the social ways of living - and imagining - it became a persistent object of analysis in dissertations and theses.

Memorialists also made continuous comparisons with the "golden age" of the cities, almost always connecting the lifestyle of their central area to that from the large metropolises, which served as inspiration for the former. The reason for this look back may be associated with the crisis of the modern culture, including its projects and its metanarratives. Fast changes, such as deep urban reforms, or even those incited by catastrophic events - a war or a diaspora, for example - can motivate a particular social group to organize a set of memories, associated with places or practices; corroborating the claim that people tend to value things they cannot have anymore.

In the 1970s, historiography became fragmented and the themes of memory and historical heritage were put on the agenda. According to Hartog (1997), since then, there has been a wave of concerns with memory and heritage which resulted in the revitalization of historic centers and museums in France, establishing a presentist temporality. In line with the author, a set of transformations started to take place at that moment. In his words:

\footnotetext{
${ }^{1}$ Works such as: NASCIMENTO, M.; TORRESINI, E. (Org). Modernidade e urbanização no Brasil. Porto Alegre: EDIPURS, 1998.; KRAWCZYK, F. (Org.). Da necessidade do moderno: o futuro da Porto Alegre do século passado. Porto Alegre: Unidade Editorial, 2002.; PANIZZI, W.; ROVATTI, J. Estudos Urbanos: Porto Alegre e seu planejamento. Porto Alegre: Ed. Universidade/UFRGS/ Prefeitura Municipalde Porto Alegre, 1993; and BISSÓN, C. A. (Org). Sobre Porto Alegre. Porto Alegre: Ed. Universidade/UFRGS/ Secretaria de Cultura do Estado do Rio Grande do Sul, 1993. A piece like "Sobre Porto Alegre", organized by Carlos Bissón, in 1993 , in a more literary scope, is also an example of this search for parameters to think the history and the identity of the city. 2 HARTOG, F. O tempo desorientado - tempo e história - "Como escrever a história da França?". Anos 90, Porto Alegre: n. 7, p. 7, jul. 1997.
} 
In this gradual invasion of the horizon by a present increasingly swollen, hypertrophied, it is clear that the leading role was represented by the fast extension and by the increasing demands of a consumer society, where scientific findings, technical innovations and pursuit of profit make men and things obsolete, at an ever-increasing pace. Media, whose extraordinary development followed this movement which is, in the true sense, its reason for being, operates in the same way: producing, consuming and recycling, ever faster, words and images. ${ }^{3}$

Within this context, some effects were noticeable in the city of Porto Alegre: a greater concern about retrieving memory and preserving historic buildings emerged in the 70s. For that matter, according to Possamai (2002), the preoccupation about historical heritage became relevant when the city reached the stage of significant urban changes. The author states that "the common view at that time, present in newspapers and among the respondents, shows that the city, in a metropolization process, was bringing down the last buildings that linked it to earlier times". ${ }^{4}$

In a more recent work, the author brings the focus of her studies back to the 20s and 30s, when "Porto Alegre goes through one of its most remarkable urban changes". Investigating photo albums from that time, the researcher pointed that the great majority of images had as objects the icons related to modernity:

Photographing downtown, favoring it in the photo albums, [...] means to transpose to the whole of the city a visual image according to the standards of an imagery which sought as benchmarks the streets, the buildings, the squares, the vehicles and, especially, the man in public spaces. ${ }^{6}$

In the same line of thought, the architect Nara Machado (1998), in a comprehensive study about urbanism and the influence of modern ideas in the downtown area of Porto Alegre, highlights the attempt of overcoming the colonial past of the city - which is associated with debasement - and also the attempt of anticipating the future, transferring to the present the "possibility of a new age". The consequences of that "world of ideas" put into practice were so severe that Porto Alegre was nicknamed "city of scaffolds"

\footnotetext{
${ }^{3}$ Ibidem, p. 13. (Own translation)

${ }^{4}$ POSSAMAI, Z. R. Entre o guardar e o celebrar: memórias, documentos e peças de museu. In: KRAWCZYK, F. Da necessidade do moderno: o futuro da Porto Alegre do século passado. EU/Secretaria Municipal de cultura, p. 41, 2002.
}

${ }^{5}$ POSSAMAI, Z. Memória e esquecimento nos álbuns fotográficos - Porto Alegre décadas de 20 e 30. Porto Alegre: 2005. Tese (Doutoramento em História) - Programa de Pós-Graduação em História - UFRGS, 2005.

${ }^{6}$ Ibidem, p. 209. 
during the 1940s. Focusing on the period from 1928 to 1945, the research emphasizes the hegemony of an ideology and its profound spatial and symbolic repercussions. The outcome is, nowadays, reason for certain anthropologic "strangeness", as far as the evolution of the city takes other paths.?

In the work "Porto Alegre: Voluntários da Pátria e a experiência da rua plurifuncional (1900 -1930)", Leila Mattar (2001) conducts a research in which one of the most famous streets in Porto Alegre is contextualized by the modern set of ideas: lifestyle and urban changes are presented as interpretations of the Paris-inspired urban reforms in Rio de Janeiro. In this work, again, the analysis started from the observation of the current state of a particular street in the city, to figure out how that modern project has collapsed. ${ }^{8}$

Another valuable research connecting modern ideas to spatial and imaginary alterations provides an examination of the expansion of apartment buildings on Independência Avenue. According to the author, Lima (2005), the influence behind them was notoriously North American, which sees verticality as a symbol of sophistication. She draws attention to the fact that the new buildings had commercial space on the ground floor, reproducing the aesthetics of the public realm of downtown, and highlighting that imagery. ${ }^{9}$

In a broader temporality, Monteiro (2000) examines the historiographic and literary production in two moments of great urban changes: the administration of Loureiro da Silva (from 1937 to 1943) and of Telmo Thompson Flores (from 1969 to 1974). The author states that in those contexts the demand for the city history was stronger: the urban disruption sparked a preservation movement, retrieving urban memories and symbolic references as a counterpoint to the transformations from that time. Thereby, the author centers his analysis in the works of Achylles Porto Alegre, reissued in the 1940s and Nilo Ruschel in the $1970 \mathrm{~s}^{10}$. In the latter, the theme of the modern city going through drastic transformations is remedied by the encounter with the downtown area of Porto Alegre, represented by Rua da Praia

\footnotetext{
7 MACHADO, N. H. Modernidade, arquitetura e urbanismo: o centro de Porto Alegre (1928 - 1945). Porto Alegre: 1998. Tese (Doutoramento em História do Brasil) - IFCH/PUCRS, 1998.

${ }^{8}$ MATTAR, L. Porto Alegre: Voluntários da Pátria e a experiência da rua plurifuncional (1900 - 1930). Porto Alegre: 2001. Dissertação (Mestrado em História) - PUCRS. 2001. pp. 61 e 103.

9 LIMA, R. R. Edifícios de apartamento: um tempo de modernidade no espaço no espaço privado. Estudo da radial Independência - 24 de Outubro - nos anos 50. Porto Alegre: 2005. Tese (Doutorado em História) - IFCH/PUCRS, p. 289, 2005.

10 PORTO ALEgRE, A. História popular de Porto Alegre. Porto Alegre: Prefeitura Municipal, 1940; and RUSCHEL, N. Rua da Praia. Porto Alegre: Prefeitura Municipal, 1971.
} 
Street. Ruschel's chronicles, as Monteiro states, "sought to recover the memory of everyday practices in 'another' city, situated in the past." 11

Also in "spaces of memory and sociability" we undertake a search for reunion with a strange and, at the same time, fascinating world in the "modern" Porto Alegre from the beginning of the century until the $1930 \mathrm{~s}^{12}$. During this time, there was a translation of the international public life on the main streets of the city, and especially on Rua da Praia; a sort of adaptation of metropolitan ideas to the local reality. The modern ideas were expressed through urban transformations, fashions of all kinds, literature and the conviviality. Paris, particularly, as well as London and New York became role models of modern cities: French novels were read by high school students; pictures of great American buildings were present in the Globo magazine; the desire of "living the urban life" followed poets and politicians in the province that longed to be a metropolis. The eagerness to build a great city was strongly felt, fact that exposed the sentiment of backwardness. ${ }^{13}$

The urban novels by Érico Veríssimo and "The rats" by Dyonélio Machado, among other important titles, indicate that the theme of modernity and its aesthetics were on the agenda in the $1930 \mathrm{~s}^{14}$. The works mentioned above reflect the ideas that circulated through the mental images of the time: the "metropolis" was the living scenario of new tensions; narcissistic individualism and poverty contrasted in a space that encouraged freedom and allowed anonymity; the hegemonic project of a city filled with skyscrapers and huge avenues shared the scene with the heterogeneity of its residents. ${ }^{15}$

Following the same line of thought, the memoirs published later by intellectuals, such as Augusto Meyer, Theodomiro Tostes and Nilo Ruschel (aforementioned), who experienced the "other" city intensely and reveal, several times, the nostalgia for a "lost modernity" ${ }^{16}$. In the 1970s, when those texts were published, the future of the city was not a positive certainty anymore; the past, glorified as "the golden age"

\footnotetext{
${ }^{11}$ MONTEIRO, C. Porto Alegre e suas histórias. Histórias e memórias (1940-1972). São Paulo: 2000. Tese (Doutoramento em História) - PUC/SP, 2000. p. 356.

12 MARONEZE, L. A. Espaços de Sociabilidade e Memória: fragmentos da vida pública porto-alegrense entre os anos 1890 -1930. Porto Alegre: 1994. Dissertação (Mestrado em História do Brasil) - PUCRS, 1994.

13 Ibidem, p. 107.

${ }^{14}$ VERÍSSIMO, É. Caminhos Cruzados. 4. ed. Porto Alegre: Globo, 1973; Clarissa. São Paulo: Companhia das Letras, 2005; 0 resto é silêncio. Porto Alegre: Globo, 1943; MACHADO, D. Os Ratos. 19. ed. São Paulo: Ed. Ática,. 1996.

15 CRUZ, C. Literatura e cidade moderna - Porto Alegre 1935. Porto Alegre: EDIPUCRS, 1994.

${ }^{16}$ MEYER, A. No tempo da flor. Rio de Janeiro: Ed. O cruzeiro, 1966; TOSTES, T. Bazar e outras crônicas. 2. ed. Porto Alegre: Fundação Paulo do Couto e Silva: IEL, 1994; 1989. RUSCHEL, op. cit. . Nosso Bairro: memórias. Porto Alegre: Fundação Paulo do Couto e Silva,
} 
of the city, became the parameter for comparison in studies about contemporary society. It seems to be the moment when the limits of the cherished modernization project were perceived; the transformation of the provincial city into a metropolis resulted in something unexpected: the "dehumanization" of the city center and the emergence of slums in the periphery, nowhere near the glamour once imagined. ${ }^{17}$ The idea of a positive future was at risk, from that moment on.

Even though some authors rightly call the attention to the "myth" of a perfect past, they cannot fail to recognize the profound and irreparable differences between the two moments. Cláudio Elmir (1995), when investigating the decades of 1950s and 1960s in Porto Alegre, attempts to show that the idea of a golden age in Porto Alegre is a myth; however, the empirical information presented establishes a rupture in the way of living the city. The period that goes from the military coup to the big urban reforms in the 70s seems to be the end of "the provincial Porto Alegre"; before that, though, "in the memories of the city, the 'golden age' concept had always been present in the claim that the street was a safe place to live".18 With open doors and no security bars, the urban aesthetics favored much more the encounter than the conflict. In contrast, in the 80s, "at the end of this time of memory, the night becomes a sign of danger as the faces of the residents are undifferentiated; they do not recognize each other anymore". 19 The celebrated Rua da Praia was then seen by some intellectuals as a "Persian bazaar", attended by "lombrosian" figures. ${ }^{20}$ It was, therefore, not a myth, but the evidence of a considerable distance that, in fact, can only be understood when the city is inserted in a broader context. Elmir (1995) brings a valuable image to the line of interpretation proposed here. In his words:

What actually amazes memorialists from the 90 s is finding the blend that exposes a lost unity. The nostalgia that covers those memories is similar to that of a spiritual exiled from the city. There is the terrible awareness of the impossibility of restoring that space named by the present as "golden years". ${ }^{21}$

Between the utopian metropolis project, which carries the awareness of backwardness, and the actual result of the ideas that merged in the specific process of modernization of the city, the feeling

\footnotetext{
17 METRÓPOLE OU PROVÍNCIA? Zero Hora, Porto Alegre: 06 mai. 1976.

${ }^{18}$ ELMIR, C. P. Os anos dourados de Porto Alegre: a construção de um mito da idade de ouro na memória da cidade. In: HAGEM, A.; MOREIRA, P. Sobre a rua e outros lugares: reinventado Porto Alegre. Porto Alegre: Caixa Econômica Federal, p. 139 e $145,1995$.

19 Ibidem, p. 146.

20 GONZAGA, S. Confissões de um adolescente interiorano. In: BISSON, C. (Org.). Sobre Porto Alegre. Porto Alegre: Ed. Universidade/UFRGS/Secretaria da Cultura do Estado do Rio Grande do Sul, p. 140, 1993.
}

${ }^{21}$ ELMIR, op. cit. p. 147. 
of frustration arises, for a Porto Alegre that "was not". In this respect, Luis Fernando Veríssimo (2003), commenting on the crisis of modernity in the city, states: "in the end, what we miss most about the past is its future." 22

The distance between the project and the result seems intrinsic to the modern achievements; the distrust of the urban processes is not particular of Porto Alegre, naturally. The crisis of the modern ideas in the Western world obstructs all areas, from economy to sociability, from architectural materiality to the imagery.

Historical problems thrive from the present, and the reality presented nowadays by the media, analyzed by social scientists or chroniclers, among others, describes large Brazilian cities as chaotic. Expressions such as "civil war", "urban violence", lack of prospects, etc. are part of an everyday speech and widely felt by the population, while the mechanisms of public order reflect the inoperativeness of the State (in all levels). Thus, when describing the "public life" of the old modern city, on the one hand, we are talking about privatization of contemporary life, an escape from the streets, occasionally replacing them with virtual encounters. The streets and squares, which allowed political meetings, economic and cultural exchanges, and thought as quintessentially the symbolic places of the modern historical process are replaced, at least in part, by urban fiefdoms. The spread of enclosed condominiums, with safe spaces for key sociability, express the decline of the citizen and the affirmation of the condominium member.

The distrust in the present and in the future of the modern city is an issue that has concerned city planners and social researchers for some decades and that leads to a context of serious apprehensions.

\section{THE CRISIS OF MODERNITY AND ITS IMPLICATIONS}

According to Morin (1991), after five hundred years modernity agonizes at the turn of the century. Its crisis reaches gigantic proportions because modernity

[...] was not just a historical phenomenon, it was not only a central idea, it was a belief and, in fact, it was built in the nineteenth century in a religion that did not see itself as such, for it was based on what had been imposed against the revealed Religion: materialist science, secular reason, historical progress. ${ }^{23}$

\footnotetext{
22 VERISSÍMO, L. F. O futuro não é mais o que era. Zero Hora. Porto Alegre, p. 3, 30 out. 2003.

${ }^{23}$ MORIN, E.; BOCCHI, G. CERUTI, M. Os problemas do fim do século. Lisboa: Editorial Notícias, p. 9, 1991.
} 
The bomb dropping in Hiroshima, in 1945, brought ambivalence to the idea of scientific progress, so cherished by the modernity enthusiasts. Soon after that, with the collapse of Stalinism and its scandals, Socialism lost its redeeming perspective; the events in Eastern Europe in 1989 buried the "radiant future" of the revolution and brought a crisis of the future instead. ${ }^{24}$

Morin's opinion (1991) is that science is blind when it comes to its own destiny: the techniques it produces many times escape the control and the awareness of scientific thinking itself; rationality without self-criticism becomes a blind and illogical delusion. Therefore, the future no longer means development; it becomes uncertainty. ${ }^{25}$ This situation, at the beginning of the century linked a crisis of the past, triggered by modernity itself, to a crisis of the future, which undermined modernity. In this context, the author states that there are two possible solutions: neo-fundamentalism, which is the desire to take root and go back to the source of tradition; and postmodernism, that, disregarding the future, breaks with history and becomes blind to bifurcations on the way. ${ }^{26}$

There is, therefore, a crisis of references when it comes to thinking modernity and life in the big cities nowadays. For authors such as Baudrillard 27 and Giddens $(2003)^{28}$, the globalization process formed the basis of these issues. The points mentioned above also go through, somehow, the problem of the acceleration of economic and cultural exchanges, which have increased in an unprecedented way for the last 40 years, and that have not been fully understood yet.

Giddens (2003), for example, understands that globalization affects all areas of life and imposes a complicated path upon everyone. For the British sociologist, this is an absolutely revolutionary process. Globalization is political and cultural as much as it is economical, and it "was influenced, above all, by the development in communication systems that date back only to the end of the 1960s".29 It does not change only the international financial system, but also enters cities and homes. Family traditions, relations among states and the global ecologic risk have also been strongly altered by it. In his words:

Nations face today more risks and dangers than enemies, which represents a huge transformation in their very nature. These comments do not apply only to nations.

\footnotetext{
24 Ibidem, p. 10.

25 Ibidem, p. 11.

${ }^{26}$ Ibidem, p. 13.

${ }^{27}$ BAUDRILLARD, J. Power Inferno. Requiem para as Twin Towers. Porto Alegre: Sulina, 2003.

${ }^{28}$ GIDDENS, A. Mundo em descontrole. O que a globalização está fazendo de nós. 3. ed. São Paulo: Record, 2003.

29 Ibidem, p. 21.
} 
Everywhere we look, we see institutions that, from the outside, look the same as always, and have the same names, but inside they have become very different. We keep talking about nation, family, work, tradition, nature, as if they are all the same as in the past. They are not. The shells remain, but inside they have changed - and this is happening not only in the US, Great Britain or France, but almost everywhere. They are what we call "shell institutions" - institutions that have become inadequate for the functions they are called to perform. ${ }^{30}$

According to the author, the "unmanageability" is, therefore, strictly linked to the expansion of a global cosmopolitanism that standardizes the contemporary world, affecting fundamentally the ideas that helped defining society.

Baudrillard's perspective (2003) also points out to the crisis of modern ideas. For him, terrorism, fanaticism and nihilism are linked to globalization and they are the outcome of a "universal" culture. While the latter represents the modern order, illuminist, the former puts itself in an inverted perspective. Universality is linked to human rights, democracy and individual freedom; globalization, in turn, is related to the market, technology and information media. In a world of large commercial trades, there is no space for the universalization of principles. The single mindset triumphs over the universal one. For him, "universal was a transcendence culture, of subject and concept, of reality and representation. The virtual space of the global is the screen, the web, the immanence, the digital, a time-space with no dimension".31

We are, therefore, discussing a matter of context. Great minds from different areas and different theoretical orientations present similar interpretations to circumscribed problems. Information technology and its effects are behind this acceleration of time, which generates an "unmanageability" of references and a search for the modern memory. The sociologist Fernando de Barros (2001), science and technology analyst at CNPq - National Council for Scientific and Technological Development, describes a set of opinions from Brazilian scientific intellectuals about the context being discussed here:

It is a historical period marked by broad disruption in the organizations, delegitimization of institutions, weakening of important social movements and ephemeral cultural expressions; the economies of the entire world, in form of variable geometry, started to maintain certain global interdependence, presenting a new kind of relationship among economy, State and society; the division of labor happens not according to territory jurisdictions - but predominantly according to a complex pattern of interconnected webs; wealth, facilitated by exceptional growth in human history, moves in a contrasting

\footnotetext{
30 Ibidem, p. 28. (Own translation).

${ }^{31}$ BAUDRILLARD, op. cit. p. 55.
} 
way to the increase in exclusion, expressed in the poverty that spreads in the African, South-American and Asian continents; social conflicts have increased exponentially, manifesting themselves, among many examples, in the expansion of urban violence and a great number of wars; political systems are immersed in structural crises; populations tend to regroup around primary identities: religious, ethnic, territorial, national. ${ }^{32}$

The backdrop to this environment is represented by the media, which established the standards of the social fabric, redrafting the order of things in a sort of anarchic way. Besides mass media, around the mid-90s, computer-mediated communication emerged. This fusion called multimedia ended up invading all spaces of everyday life, indifferent to social complexity: politics and market started to happen in real time, opposing the "Web" to the "Being"."3

Those transformations, connected to the communication world, create a virtual space which is deeply rooted in the daily life of almost every society on the planet. According to the philosopher Pierre Lévy (1999), we have a universal without totality:

Cyberspace is a system of systems, but by this very fact, it is also a chaotic system. The maximum embodiment of technical transparency, through its irrepressible activity, it shelters opacities of meaning. Cyberspace ceaselessly redefines the outlines of a mobile and expanding labyrinth that cannot be mapped, a universal labyrinth beyond Daedalus's wildest dreams. I refer to this universality without any centralized meaning, this system of disorder and labyrinthine transparency as the "universal without totality": the essence of cyberculture. ${ }^{34}$

Lévy's opinion about what he calls "cyber culture" is less negative, however, about the possibilities of the virtual space and its relationships with the "urban". He suggests that the effects of cyberculture are ambivalent in relation to the physical space of the cities and that the deterritorialization of great centers is the result of a broad historical trend, and not caused by communication webs. ${ }^{35}$ He refutes, then, the idea that the virtual space can serve as substitute for physical encounters and the busy streets; it shows,

\footnotetext{
32 BARROS, F. Os avanços da tecnociência, seus efeitos na sociedade contemporânea e repercussões no contexto brasileiro. In: BAUMGARTEN, M. (Org.). A era do conhecimento: Matriz ou Agora? Porto Alegre/Brasília: Ed. Universidade/UFRGS/Unb, 2001. p. 76-77. (Own translation).

33 Ibidem, p. 78.

${ }^{34}$ LÉVY, P. Cibercultura. São Paulo: Ed. 34, p. 111, 1999.

35 Ibidem. p. 190. (Own translation).
} 
on the contrary, that the growth in telecommunication is parallel to the growth in physical transportation, to conclude that "the more we communicate, the more we move around". ${ }^{36}$

The author notices, however, that political forces do not vanish with the web, and that big Northern companies tend to interfere deeply in local cultures. It is the case, for example, of "teleuniversities", training "teleworkers" in Asia, for a global market. Nevertheless, as the author suggests, this ubiquity of the web could also allow new strategies for local responses to the global, from self-organizations that translate the endogenous in the cyber culture flow. His idea is that the point is not to be for or against these irreversible historical facts, but to understand them so that we can interfere in a positive way. About the impact of this culture in the urban world, he comments:

\footnotetext{
Within our perspective, interactive communication networks should have as their primary focus the reconstruction of urban sociability, self-management of the city by its residents and real-time control of collective equipment instead of replacing the concentrated diversity, physical interaction and direct human exchange, that are, more than ever, the main attraction of urban life. ${ }^{37}$
}

In any case, these matters end up reflecting in the West, according to the shades of each context and they can be perceived not only in architectural ideas, but also in social relations and the ways of expressing experiences subjectively. The emptying of the collection of modern ideas, which has set the pace of historical flow, brings consequences that go beyond the possibility of a precise understanding by those living the process, allowing only circumstantial approach.

\section{FINAL CONSIDERATIONS}

Starting from the reading of major works about present and future perspectives of the modern city, especially in its metropolitan form inserted in a globalized context, it was found that intellectuals of several areas show strong reservations when it comes to the future of big cities in the Western culture. Even though there are many differences among their points of view, the authors point, in a way or another, to a "crisis of the future", contradicting modern ideas - which proposed an optimistic teleology. This background is present in the specific history of Porto Alegre as well.

The chroniclers of the cities, who investigate life from an everyday perspective, are excellent sources to understand the crisis of the modern city and its ramifications. In the case of Porto Alegre, which until

\footnotetext{
36 Ibidem, p. 189.

37 Ibidem, p. 191. (Own translation)
} 
the 1970s grew cradled by the dream of the modern utopia - where the perfect future guided and brought the society together - the chronicles show a contradiction between project and outcome. The old modern public life, which incited street interactions and celebrated the refined sociability translated to the big centers, strongly declined in the last four decades. It is possible to notice, in those written pieces, a feeling of nostalgia for the lost modernity.

Important academic references report that the central ideas of the utopia of modernity have lost their encompassing force, and the optimistic beliefs regarding a rational, scientific and harmonious future have given ground to skepticism and fragmentation. The public space, foundation of modern sociability and the space of the political individual has lost its meaning. The city, as a stage, reveals these changes, calling for a microsocial observation of greater ideas.

This is History, never fully understood, never completely mastered. The reality of the crisis of modernity must be approached as a historical process to be learned and overcome. The modern dream had everything arranged in its project, but it also had many things concealed. That is the reason why it is essential to analyze the whole context and its dynamics, for all areas of knowledge and of life depend on the solutions presented to these affairs.

\section{BIBLIOGRAPHY}

BAUDRILLARD, J. Power Inferno. Requiem para as Twin Towers. Porto Alegre: Sulina, 2003.

BARROS, F. Os avanços da tecnociência, seus efeitos na sociedade contemporânea e repercussões no contexto brasileiro. In: BAUMGARTEN, M. (Org.) A era do conhecimento: Matriz ou Agora? Porto Alegre/ Brasília: Ed. Universidade/UFRGS/Unb, p. 76-77, 2001.

BISSÓN, C. A. (Org.). Sobre Porto Alegre. Porto Alegre: Ed. Universidade/UFRGS/Secretaria de Cultura do Estado do Rio Grande do Sul, 1993.

CRUZ, C. Literatura e cidade moderna: Porto Alegre 1935. Porto Alegre: EDIPUCRS, 1994.

ELMIR, C. P. Os anos dourados de Porto Alegre: a construção de um mito da idade de ouro na memória da cidade. In: HAGEM, A.; MOREIRA, P. Sobre a rua e outros lugares: reinventado Porto Alegre. Porto Alegre: Caixa Econômica Federal, p. 139 e 145, 1995. 
GIDDENS, A. Mundo em descontrole. O que a globalização está fazendo de nós. 3. ed. São Paulo: Record, 2003.

GONZAGA, S. Confissões de um adolescente interiorano. In: BISSON, C. (Org.) Sobre Porto Alegre. Porto Alegre: Ed. Universidade/UFRGS/Secretaria da Cultura do Estado do Rio Grande do Sul, p. 140, 1993.

HARTOG, F. O tempo desorientado - tempo e história - "Como escrever a história da França?". Anos 90, Porto Alegre, n. 7, p. 7, jul. 1997.

KRAWCZYK, F. (Org.). Da necessidade do moderno: o futuro da Porto Alegre do século passado. Porto Alegre: Unidade Editorial, 2002.

LIMA, R. R. Edifícios de apartamento: um tempo de modernidade no espaço no espaço privado. Estudo da radial Independência - 24 de Outubro - nos anos 50. Porto Alegre: 2005. Tese (Doutorado em História) - IFCH/PUCRS, p. 289, 2005.

LÉVY, P. Cibercultura. São Paulo: Ed. 34, 1999. p. 111.

MACHADO, D. Os Ratos. 19. ed. São Paulo: Ed. Ática, 1996.

MACHADO, N.H. Modernidade, arquitetura e urbanismo: o centro de Porto Alegre (1928-1945). Porto Alegre: 1998. Tese (Doutoramento em História do Brasil) - IFCH/PUCRS, 1998.

MARONEZE, L.A. Espaços de Sociabilidade e Memória: fragmentos da vida pública porto-alegrense entre os anos 1890-1930. Porto Alegre: 1994. Dissertação (Mestrado em História do Brasil) - PUCRS, 1994.

MATTAR, L. Porto Alegre: Voluntários da Pátria e a experiência da rua plurifuncional (1900-1930). Porto Alegre: 2001. Dissertação (Mestrado em História) - PUCRS, p. 61 e 103, 2001.

METRÓPOLE OU PROVÍNCIA? Zero Hora, Porto Alegre: 06 mai. 1976.

MEYER, A. No tempo da flor. Rio de Janeiro: Ed. O cruzeiro, 1966.

Nosso Bairro: memórias. Porto Alegre: Fundação Paulo do Couto e Silva, 1989.

MORIN, E.; BOCCHI, G. CERUTI, M. Os problemas do fim do século. Lisboa: Editorial Notícias, p. 9, 1991. 
MONTEIRO, C. Porto Alegre e suas histórias. Histórias e memórias (1940-1972). São Paulo: 2000. Tese (Doutoramento em História) - PUC/SP, p. 356, 2000.

NASCIMENTO, M.; TORRESINI, E. (Org.). Modernidade e urbanização no Brasil. Porto Alegre, EDIPURS, 1998.

PANIZZI, W. ROVATTI, J. Estudos Urbanos: Porto Alegre e seu planejamento. Porto Alegre: Ed. Universidade/UFRGS/Prefeitura Municipal de Porto Alegre, 1993.

PORTO Alegre, A. História popular de Porto Alegre. Porto Alegre: Prefeitura Municipal, 1940.

POSSAMAI, Z. Entre o guardar e o celebrar: memórias, documentos e peças de museu. In: KRAWCZYK, F. Da necessidade do moderno: o futuro da Porto Alegre do século passado. EU/Secretaria Municipal de cultura, 2002. p. 41.

POSSAMAI, Z. Memória e esquecimento nos álbuns fotográficos - Porto Alegre décadas de 20 e 30. Porto Alegre: 2005. Tese (Doutoramento em História) - UFRGS, 2005.

RUSCHEL, N. Rua da Praia. Porto Alegre: Prefeitura Municipal, 1971.

TOSTES, T. Bazar e outras crônicas. 2. ed. Porto Alegre: Fundação Paulo do Couto e Silva: IEL,1994.

VERÍSSIMO, É. Caminhos Cruzados. 4. ed. Porto Alegre: Globo, 1973

. Clarissa. São Paulo: Companhia das Letras, 2005

. O futuro não é mais o que era. Zero Hora. Porto Alegre, p. 3, 30 out. 2003.

. O resto é silêncio. Porto Alegre: Globo, 1943. 